\title{
Food habits and food preferences of black South African men in the army (1993-1994) *
}

\section{Annemarie T Viljoen and Gertruida J Gericke}

\section{OPSOMMING}

Beperkte inligting is beskikbaar oor die eetgewoontes en voedselvoorkeure van die Suid-Afrikaanse bevolking. Die eetgewoontes en voedselvoorkeure van mans (16-25 jaar) wat dienspligtig was ten tye van die studie, 1993 tot Maart 1994, is bepaal. Die resultate van die studie het daarop gedui dat die sewe etniese groepe (blankes, kleurlinge, NoordSotho's, Suid-Sotho's, Tswanas, Xhosas en Zoeloes) in twee groepe verdeel kan word op grond van ooreenkomste in hulle eetgewoontes en voedselvoorkeure. Die blankes en kleurlinge, wat beide tipiese Westerse eetpatrone en voedselvoorkeure gerapporteer het, het ' $n$ groep gevorm, en die vyf swart etniese groepe het ' $n$ tweede groep gevorm.

In ' $n$ vergelyking tussen die tradisionele en huidige eetgewoontes van die swart bevolkingsgroepe in Suid-Afrika, is daar 'n duidelike verandering opgemerk. Die tradisionele eetpatroon en maaltydsamestelling is gedeeltelik vervang deur ' $n$ tipiese Westerse eetpatroon en maaltydsamestelling. In ooreenstemming met vorige studies is daar ook gevind dat drie maaltye per dag teenoor die tradisionele twee maaltye per dag algemeen voorkom. Die maaltydsamestelling word gekenmerk deur die insluiting van meer Westerse voedselitems.

Die eetgewoontes en voedselvoorkeure van die vyf swart etniese groepe word in hierdie publikasie gerapporteer.

\section{- Mrs AT Viljoen}

Department of Consumer Science

University of Pretoria

\section{- Ms GJ Gericke}

Division of Human Nutrition, Faculty of Medicine University of Pretoria

* Based on an M Dietetics thesis under the supervision of Ms GJ Gericke

\section{ACKNOWLEDGEMENTS}

The authors wish to thank:

- Armscor for financing this research project

- Capt Corlia Prinsloo of the Catering Corps of the South African Army for her much appreciated assistance with data collection

- Mrs Ansie Blignaut of Armscor for her valuable assistance with data analysis.

\section{BACKGROUND}

South Africa is a developing country with a heterogeneous socioeconomic and multicultural society. A nutrition in transition has been noticed, characterised by a change from traditional eating patterns to those typical of a Western lifestyle, with the increased risk of noncommunicable diseases. Data on food habits, preferences and eating patterns may be used in menu planning and could help combat the negative impact of this nutritional transition.

Since World War II the Armed forces of America have done comprehensive studies on the food habits and food preferences of servicemen (Peryam, 1963). However, very little information in this regard is available in South Africa. Food habits are dynamic and therefore constantly change. During the past four decades studies on the black ethnic groups in South Africa indicated changes in the food habits of these groups. These changes are mainly due to acculturation after urbanisation and improved transport and communication technology (Popkin, 1994; Walker, 1995; Van Eeden \& Gericke, 1996).

This study (Viljoen, 1996) determined the food habits and food preferences of seven different ethnic groups enlisted in the South African Army between 1993 and March 1994. The ethnic groups included whites, coloureds, North Sothos, South Sothos, Tswanas, Xhosas and Zulus. The findings are reported separately due to similarities and/or differences identified in the food habits and preferences of these groups.

This article reports on the food habits and food preferences of the black ethnic servicemen.

\section{EATING PATTERNS AND FOOD PREFERENCES OF BLACK ETHNIC GROUPS IN SOUTH AFRICA}

The southern black ethnic groups of Africa developed from the Negroid race that originally lived in the vicinity of the Great Lakes of Africa. Over the centuries these races slowly moved south (Hammond-Tooke, 1993:24). Eventually four main groups crossed the Limpopo River. Four main groups - the Nguni, Sotho, Venda and Tsonga - form the black population of the Republic of South Africa. The groups settled in South Africa in four main geographical and ecological regions (Hammond-Tooke, 1993:14). This southward movement stabilised towards the end of the eighteenth century when people settled in organised groups and subgroups, each group developing a recognisable cultural pattern (Hammond-Tooke, 1993:39). 


\section{Traditional eating patterns of the four main groups}

The traditional ethnic groups lived on what the environment had to offer. The most important staple cereals were sorghum (Andropogon sorghum), together with millet (Pennissetum spicatum) and later maize (Zea mays). Sugar cane (Sorghum vulgarus), peas, beans and groundnuts, sweet potatoes and different species of the cucurbit (melon and pumpkin) were also cultivated. Although they kept cattle, goats and sheep, animals were only slaughtered for ceremonial occasions and ancestral worshipping. Cattle were considered a symbol of wealth and not a food source. Meat was therefore not part of the daily diet.

These groups usually consumed two meals per day. The first meal was served in midmorning (at about eleven o'clock) and consisted of porridge prepared from the staple cereal and a vegetable-based relish (merôgô) or a legume and vegetable sauce (Lestrade, 1937:122; Quin, 1959:261; Crous \& Borchardt, 1986). The second meal of the day (supper) consisted of the same dishes as the first meal of the day, but was a more substantial meal. The relish, meat-based gravy or a substantial vegetable dish, was served together with the porridge (Lestrade, 1937:126).

\section{Changes in food habits of black ethnic groups}

Studies of the food habits of the different black ethnic groups in South Africa during the past four decades indicated noticeable changes (Walker, 1962; Oudkerk, 1965; Leary, 1969; Manning et al, 1974; Crous \& Borchardt, 1982; Brink \& Boshoff, 1983; Crous \& Borchardt, 1984; Gericke et al, 1987; Steyn et al, 1993; Walker, 1995; Van Eeden \& Gericke, 1996), mainly due to acculturation as a result of urbanisation, improved transport and communication technology (Popkin, 1994; Walker, 1995). Changes in the distribution and composition of the meals were the most evident.

Meal pattern In contrast to the traditional two meals per day, studies on the food habits of urban and rural blacks revealed that they now commonly enjoyed three meals per day (Oudkerk, 1965; Lubbe \& Maree, 1973; Crous \& Borchardt, 1982; Brink \& Boshoff, 1983; Crous \& Borchardt, 1984; Steyn et al, 1993; Van Eeden \& Gericke, 1996).

Meal composition Several studies indicated that the traditional meal of maize porridge and a relish is still consumed as the main meal on weekdays (Oudkerk, 1965; Leary, 1969; Lubbe \& Maree, 1973; Brink \& Boshoff, 1983; Crous \& Borchardt, 1982, 1984; Steyn et al, 1993).

Some studies reported a different eating pattern on weekdays and weekends. The following were reported meals during weekdays:

- Breakfast consisted of a soft maize porridge with sugar and or brown bread, jam and tea (Oudkerk, 1965; Leary, 1969; Crous \& Borchardt, 1982).
- Lunch consisted of stiff maize porridge and a relish of gravy, vegetables or tomatoes (Oudkerk, 1965; Brink \& Boshoff, 1983).

- Supper (the main meal of the day) consisted of stiff maize porridge and meat (if affordable) gravy, or vegetable stew prepared with cabbage (Oudkerk, 1965; Leary, 1969; Brink \& Boshoff, 1983).

The meal pattern and meal composition for breakfast on Sundays were different and the meal pattern more extensive:

- Oudkerk (1965) found that the breakfast (bread and tea) corresponded with breakfasts during the week.

- Crous and Borchardt (1982) reported that urban Pedi families preferred porridge and a relish to bread for breakfast.

- Manning et al (1974) found in a study in Guguletu that the more sophisticated urban black family preferred a Western breakfast of ready-to-eat cereal, bacon, eggs and sausage.

Lunch was the main meal on Sundays and the meal pattern of most groups included a meat dish with starch dishes (rice, potatoes, samp, maize porridge or mealie rice) and a variety of vegetables and salads (usually three to four kinds).

Dessert was served at the end of the meal and popular desserts were jelly and custard or canned fruit with custard (Oudkerk, 1965; Manning et al, 1974; Crous \& Borchardt, 1982; Brink \& Boshoff, 1983).

\section{Food preferences}

Various studies have identified preferred food patterns.

Staple food Most ethnic groups preferred maize products as their staple food.

- Oudkerk (1965) as well as Crous and Borchardt (1982) found that the daily diet of most of the participants in studies in the Pretoria area included maize porridge.

- A recent study by Van Eeden and Gericke (1996) found that maize meal porridge was still the most popular traditional cereal.

- Lubbe and Maree (1973) found that the daily diet of a group of Xhosas in the Transkei included samp mixed with beans.

- Their observation was confirmed by Manning et al (1974) who reported that people in the Transkei consumed samp and beans whereas others to the north of the Transkei preferred maize meal.

- Oudkerk (1965) and Crous and Borchardt (1982) reported that Sotho groups in the greater Pretoria area preferred rice to samp and mealie rice as their staple food.

- Manning et al (1974) and Van Eeden and Gericke (1996) reported that rice as a starch dish seemed to have become more popular with all the groups. 
Bread The consumption of brown bread together with maize products was increasing.

- Brown bread was eaten at breakfast (Oudkerk, 1965; Crous \& Borchardt, 1982) and at lunch and served as a snack for school-going children. People seemed to prefer brown bread to white bread, both because of the taste and the price (Manning et al, 1974; Crous \& Borchardt, 1982).

- Vetkoek prepared with cake or bread flour and / or maize meal and baking powder is a deep-fat fried product that is consumed regularly (Manning et al, 1974).

Meat Nowadays meat is consumed more often than in the past. Meat, if affordable, is included in the daily diet or at least once or twice a week (Oudkerk, 1965; Leary, 1969; Crous \& Borchardt, 1982; Van Eeden \& Gericke, 1996). Beef seemed to be the most popular meat (Oudkerk, 1965; Crous \& Borchardt, 1982; Richardson et al, 1982). According to Crous and Borchardt (1982), meat was used in the following order of preference: beef, chicken, pork, liver, ox head (beeskop), goat, bacon, mutton and venison.

Vegetables and fruit There has been a general increase in the consumption of potatoes.

- According to Manning et al (1974) potatoes were one of the first vegetables in the traditional diet after urbanisation.

- Oudkerk (1965) reported a daily consumption of potatoes and other studies indicated that it was often mixed with meat or other vegetable relishes.

- According to Oudkerk (1965) and Crous and Borchardt (1982), green leafy vegetables served in the form of a vegetable stew as a relish were still the most popular type of vegetable.

- Other studies reported the inclusion of vegetables such as onions, tomatoes, cabbage, carrots, sweet potatoes and pumpkin varieties (Manning et al, 1974; Crous \& Borchardt, 1984).

Fresh fruit was popular with urbanised black groups. Apples and oranges were the most popular fruit (Oudkerk, 1965). Canned peaches, guavas and fruit salad were served on Sundays as a dessert (Oudkerk, 1965; Manning et al, 1974; Brink \& Boshoff, 1983).

Condiments / flavourings According to Crous and Borchardt (1982) salt was used to some extent to flavour relishes. However, porridge without salt was still preferred. A study by Manning et al (1974) reported the same finding. Spices that were previously unfamiliar (curry powder, pepper, cinnamon, ginger, mustard, cayenne pepper, chilli powder, nutmeg and vinegar) are now frequently used in food preparation (Manning et al, 1974; Crous \& Borchardt, 1982). Manning et al (1974) reported a noticeable preference for the sweet-and-sour taste. The popularity of sweetand-sour beetroot and a beverage of water, sugar and vinegar reflected this finding.

Beverages Maghew has been replaced by tea as a nonalcoholic beverage for social occasions. Tea was considered as more sophisticated, and was quicker and easier to prepare (Oudkerk, 1965; Lubbe \& Maree, 1973; Manning et al, 1974; Crous \& Borchardt, 1982). Sweetened cold drinks and fizzy drinks were generally consumed (Leary, 1969; Manning et al, 1974; Crous \& Borchardt, 1982).

\section{Taboos}

Various studies reported that taboos on the consumption of certain foods were no longer strictly applied. Although fish was a prohibited food in some ethnic groups, it has been established that fish is more often consumed than in the past. Fish and chips, tinned fish and sardines were some of the fish products that were consumed (Oudkerk, 1965; Manning et al, 1974; Crous \& Borchardt, 1982). It was also reported that the prohibition on the consumption of eggs was no longer enforced (Crous \& Borchardt, 1982).

\section{METHOD}

An exploratory study in the quantitative research domain was undertaken to determine the food habits and food preferences of servicemen. Convenience sampling was used and the sample comprised the seven most representative ethnic groups in the South African Army between 1993 and March 1994. Special care was taken to ensure that the ethnic sample sizes made appropriate statistical processing possible.

A pretested, structured questionnaire was used to collect data on demographics, food habits and food preferences. Food habits were determined by questions on meal patterns and meal composition. The food preference section of the questionnaire determined familiarity with food items, food preferences and intended frequency of use. A list of 219 food items (typically served in the South African Army at the time of the study) was compiled. Preference ratings were conducted for familiar foods only. A seven-point Likert-type hedonic scale was used.

Frequency ratings (expressed as percentages) were calculated for the data on demographics, habitual eating patterns, meal composition and familiarity of food items.

The following procedure was followed for analysis of food preferences and intended frequency of use of each of 219 food items:

- The distribution of variables for food preferences and intended frequency of usage was not normal at the $5 \%$ level of significance (Shapiro \& Wilk, 1965). In view of the risk of using a global calculating method to compare the variables, this was avoided (as suggested by O'Mahoney, 1986;366).

- Median and mode values were calculated and used.

- Median values for food preferences were used to rate each food item as a high, neutral or lowpreference item.

- The indicated frequency of use (expressed as percentages) was presented as never (0 days), some- 
TABLE 1: DEMOGRAPHIC CHARACTERISTICS OF BLACK SERVICEMEN ( $\mathrm{N}=640)$

\begin{tabular}{|c|c|c|c|c|c|c|c|c|c|c|}
\hline \multirow{2}{*}{ VARIABLE } & \multicolumn{2}{|c|}{$\begin{array}{c}\text { NORTH SOTHO } \\
\mathrm{N}=163\end{array}$} & \multicolumn{2}{|c|}{$\begin{array}{c}\text { SOUTH SOTHO } \\
\mathbf{N}=68\end{array}$} & \multicolumn{2}{|c|}{$\begin{array}{c}\text { TSWANA } \\
\mathrm{N}=102\end{array}$} & \multicolumn{2}{|c|}{$\begin{array}{c}\text { XHOSA } \\
\mathbf{N}=88\end{array}$} & \multicolumn{2}{|c|}{$\begin{array}{c}\text { ZULU } \\
\mathrm{N}=219\end{array}$} \\
\hline & $\mathbf{N}$ & $\%$ & $\mathbf{N}$ & $\%$ & $\mathbf{N}$ & $\%$ & $\mathbf{N}$ & $\%$ & $\mathbf{N}$ & $\%$ \\
\hline \multicolumn{11}{|l|}{ Age } \\
\hline$<20$ years & 1 & 0,6 & - & - & 1 & 1,0 & 4 & 4,5 & 17 & 7,8 \\
\hline 20-24 years & 89 & 54,6 & 50 & 73,5 & 58 & 56,9 & 62 & 70,5 & 159 & 72,6 \\
\hline $25-29$ years & 60 & 36,8 & 17 & 25,0 & 27 & 26,5 & 16 & 18,2 & 34 & 15,5 \\
\hline $30-34$ years & 10 & 6,1 & 1 & - & 11 & 10,8 & 3 & 3,4 & - & - \\
\hline $35-39$ years & 1 & - & - & - & 1 & 1,0 & - & - & - & - \\
\hline $40+$ years & - & - & - & - & 2 & 2,0 & - & - & - & - \\
\hline \multicolumn{11}{|l|}{ Religion } \\
\hline Christian & 151 & 92,6 & 63 & 92,6 & 97 & 95,1 & 78 & 88,6 & 205 & 93,6 \\
\hline Hindu & - & - & - & - & - & - & - & - & 1 & 0,5 \\
\hline Muslim & - & - & - & - & - & - & - & - & - & - \\
\hline None & 3 & 1,8 & 2 & 2,9 & 2 & 2,0 & 1 & 1,1 & 7 & 3,2 \\
\hline Other & 5 & 3,1 & 1 & 1,5 & 1 & 1,0 & 8 & 9,1 & 3 & 1,4 \\
\hline \multicolumn{11}{|l|}{ Education } \\
\hline $\begin{array}{l}\text { Participants } \\
\text { with Std 8+ }\end{array}$ & 163 & 100 & 64 & 94 & 88 & 86 & 86 & 98 & 219 & 100 \\
\hline
\end{tabular}

times (1-3 out of 30 days), often (4-10 out of 30 days) and twice a week (11-30 out of 30 days).

The above procedure was followed separately for each of the seven ethnic groups.

The study methodology has been reported in detail (Viljoen \& Gericke, 1998).

\section{RESULTS}

\section{Demographic profile}

The demographic characteristics of the sample $(\mathrm{N}=$ 640) are represented in Table 1.

\section{Regions where participants grew up (according to} provincial boundaries before 1994)

North Sotho The majority $(69,9 \%)$ grew up in the Northern Transvaal and lived in rural areas.

South Sotho The majority $(76,4 \%)$ of these participants grew up in the Free State and the former Pretoria-Witwatersrand-Vereeniging (PWV) area. Most South Sotho participants $(67,6 \%)$ lived in urban areas.

Tswana The biggest group Tswana participants $(37,3 \%)$ grew up in the former PWV area or adjacent regions such as the Western Transvaal (13,7\%), Northern Free State $(4,9 \%)$ and Northern Cape $(17,6 \%)$. Most of the Tswana participants in this group $(56,9 \%)$ lived in urban areas.

Xhosa Most Xhosas (53,4\%) indicated that they grew up in the Eastern Cape, the PWV area $(9,1 \%)$, the Western Transvaal $(5,7 \%)$ and the Southern Free State $(4,5 \%)$. Forty-nine per cent $(48,9 \%)$ of the Xhosa participants lived in rural areas.

Zulu The majority $(82,2 \%)$ grew up in Natal and $71,7 \%$ of the Zulu participants lived in rural areas.

\section{Habitual eating pattern}

Table 2 summarises the results of the habitual eating pattern.

Number and type of meals Most of the participants $(>57,7 \%)$ indicated that they consumed three meals per day. This tendency corresponds with the findings of Oudkerk (1965), Crous and Borchardt (1982 \& 1984) and Langenhoven et al (1988). However, Bourne et al (1994) reported that only $25 \%$ of the population they had studied consumed three meals per day.

Breakfast The majority of the participants $(92,6 \%$ and more of the sample) indicated that that they consumed breakfast. 
TABLE 2: $\quad$ HABITUAL EATING PATTERN OF BLACK SERVICEMEN $(\mathrm{N}=640)$

\begin{tabular}{|c|c|c|c|c|c|c|c|c|c|c|}
\hline \multirow[t]{2}{*}{ Number of meals } & \multicolumn{2}{|c|}{$\begin{array}{c}\text { NORTH SOTHO } \\
\mathrm{N}=163\end{array}$} & \multicolumn{2}{|c|}{$\begin{array}{c}\text { SOUTH SOTHO } \\
\mathrm{N}=68\end{array}$} & \multicolumn{2}{|c|}{$\begin{array}{c}\text { TSWANA } \\
\mathrm{N}=102\end{array}$} & \multicolumn{2}{|c|}{$\begin{array}{c}\text { XHOSA } \\
\mathrm{N}=88\end{array}$} & \multicolumn{2}{|c|}{$\begin{array}{l}\text { ZULU } \\
\mathbf{N}=219\end{array}$} \\
\hline & $\mathbf{N}$ & $\%$ & $\mathbf{N}$ & $\%$ & $\mathbf{N}$ & $\%$ & $\mathbf{N}$ & $\%$ & $\mathbf{N}$ & $\%$ \\
\hline One meal & 9 & 5,5 & 3 & 4,4 & 2 & 2,0 & 4 & 4,5 & 7 & 3,2 \\
\hline Two meals & 46 & 28,2 & 5 & 7,4 & 11 & 10,8 & 3 & 3,4 & 35 & 16,0 \\
\hline Three meals & 94 & 57,7 & 49 & 72,1 & 71 & 69,6 & 70 & 79,5 & 169 & 77,2 \\
\hline $\begin{array}{l}\text { More than three } \\
\text { meals }\end{array}$ & 12 & 7,4 & 11 & 16,2 & 18 & 17,6 & 10 & 11,4 & 8 & 3,7 \\
\hline \multicolumn{11}{|l|}{ Eat breakfast } \\
\hline Yes & 151 & 92,6 & 66 & 97,1 & 99 & 97,1 & 88 & 100 & 214 & 97,7 \\
\hline No & 12 & 7,4 & 1 & 1,5 & 3 & 2,9 & - & - & 4 & 1,8 \\
\hline \multicolumn{11}{|l|}{ Main meal } \\
\hline Lunch & 72 & 44,2 & 28 & 41,2 & 40 & 39,2 & 48 & 54,4 & 104 & 47,5 \\
\hline Supper & 55 & 33,7 & 23 & 33,8 & 32 & 31,4 & 20 & 22,7 & 61 & 27,9 \\
\hline Varies & 32 & 19,6 & 14 & 20,6 & 23 & 22,5 & 15 & 17,0 & 34 & 15,5 \\
\hline \multicolumn{11}{|c|}{ Different weekend pattern } \\
\hline Yes & 118 & 72,4 & 49 & 72,1 & 81 & 79,4 & 53 & 60,2 & 121 & 55,3 \\
\hline No & 45 & 27,6 & 17 & 25,0 & 17 & 16,7 & 32 & 36,4 & 92 & 42,0 \\
\hline
\end{tabular}

Main meal The main meal of the day was reported to be the midday meal for $\geq 39,2 \%$ of the participants. This finding differs from the results obtained from the white and coloured participants who said that supper was the main meal of the day.

Different weekend meal pattern Most of the participants $(\geq 55,3 \%)$ followed a different meal pattern over weekends. The most important differences were in respect of meal composition. Table 3 summarises the differences in eating patterns (relative to the eating pattern during the week).

With the exception of the North Sotho group, $25 \%$ to $33 \%$ of the participants indicated that they enjoyed a bigger midday meal on Sundays. This finding corresponded with the results reported by Oudkerk (1965), Manning et al (1974), and Crous and Borchardt (1982, 1984). Only $17 \%$ of the North Sotho participants consumed a bigger Sunday midday meal, and $29 \%$ of this group indicated a lighter Sunday midday meal.

Foods consumed at different meals Table 4 presents a summary of the foods consumed habitually (3-4 times per week) by $\geq 40 \%$ of the participants. These foods (at a particular meal or between meals) could probably be deemed representative of the eating patterns of a particular group.

Breakfast Cooked porridge was habitually consumed by $\geq 43 \%$ of the participants. Most indicated that the porridge was eaten with milk. Bread seemed to be a regularly included food item for breakfast. These results corresponded with those reported by Oudkerk (1965) and Crous and Borchardt (1982). In contrast to traditional custom, it was found that eggs and cheese were part of the habitual eating pattern of these groups. Manning et al (1974) and Crous and Borchardt $(1982,1984)$ reported similar results. The results of this study indicated that beverages such as tea and coffee were not generally consumed by the different groups, with the exception of the Xhosas of whom $46 \%$ regularly drank coffee at breakfast.

Lunch Bread with margarine was a popular item for lunch and was consumed by between $45 \%$ and $61 \%$ of the participants. In contrast to the whites and the coloureds, the black groups $(\geq 55 \%)$ indicated that they had porridge with meat at lunch. Except for the North Sotho, the groups $(41 \%-62 \%)$ indicated that potatoes and vegetables / salads were usually (3-4 times per week) included at lunch. Manning et al (1974) also reported the tendency of increased vegetable and potato consumption in certain ethnic groups. With the exception of the North Sotho, more than $45 \%$ of the participants drank milk.

Supper Most of the participants indicated that they had meat, fish or chicken with a starch dish at supper. With the exception of the North Sotho, all the groups said that they included potatoes, rice and vegetables / salad in their meals. The North Sotho group said that their supper consisted of meat and porridge only. 

DIFFERENCE IN WEEKEND EATING PATTERNS* OF BLACK SERVICEMEN (N = 640)

\begin{tabular}{|c|c|c|c|c|c|}
\hline & $\begin{array}{c}\text { North Sotho } \\
\qquad \begin{array}{c}N=163 \\
\%\end{array}\end{array}$ & $\begin{array}{c}\text { South Sotho } \\
\qquad \begin{array}{c}N=68 \\
\%\end{array}\end{array}$ & $\begin{array}{c}\text { Tswana } \\
N=102 \\
\%\end{array}$ & $\begin{array}{c}\text { Xhosa } \\
\mathbf{N}=\mathbf{8 8} \\
\%\end{array}$ & 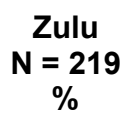 \\
\hline Breakfast is bigger & 12 & 16 & 19 & 11 & 19 \\
\hline Don't eat breakfast & 7 & 13 & 14 & 13 & 1 \\
\hline Eat lighter meals on Saturdays & 25 & 17 & 17 & 11 & 13 \\
\hline Eat bigger meal Sunday midday & 17 & 32 & 33 & 28 & 25 \\
\hline Eat lighter meal Sunday midday & 29 & 16 & 14 & 10 & 9 \\
\hline Don't eat Sunday evenings & 6 & 4 & 5 & 2 & 1 \\
\hline Eat lighter meal Sunday evenings & 23 & 10 & 21 & 10 & 11 \\
\hline Eat more between meals & 5 & 7 & 9 & 7 & 7 \\
\hline Consume more alcoholic beverages & 2 & 6 & 8 & 1 & 4 \\
\hline
\end{tabular}

* : Relative to the habitual eating pattern during the week

These results corresponded with those reported by Crous and Borchardt (1982) who found that the Pedi in Atteridgeville (Pretoria) preferred porridge for the main meal. Manning et al (1974) also reported the increased consumption of rice as a starch dish. The Zulu were the only group who said that they had fruit at supper.

In-between meals All the ethnic groups enjoyed fruit / dried fruit and peanuts. All of them, with the exception of the North Sotho, indicated that they also consumed cake and biscuits.

\section{Familiarity, food preferences and frequency of use}

In the following section, the terms "familiarity", "food preferences" and "frequency of use" defined for this study, are briefly discussed. This section is followed by a discussion of the three aspects with different food classifications as the organising mechanism. The different food types are protein-rich dishes, starch dishes, vegetable dishes, fruit, desserts and dessert sauces, breakfast cereals, bread and baked products, and beverages.

Familiarity This term refers to the extent to which certain foods are known to the subjects. The results indicated that most of the participants from the different groups, were familiar with the food items in the questionnaire and had eaten the items before. There were however, some vegetables and vegetable dishes that were unknown to / or have never been eaten before by more than $20 \%$ of the black participants. See Table 5 for information on these unknown and never eaten vegetables and vegetable dishes.

Food preferences Food preferences were determined by means of a seven-point Likert-type hedonic scale on which like it extremely (7) and dislike extremely (1) were used.
The following arbitrary criteria based on median values were used for rating the preference for each food item:

Low-preference item Any item with a median value of 1 to 3,99 (These were the items that the participants did not like.)

\section{Neutral preference item value of 4 to 4,99 \\ Any item with a median}

High-preference item value of 5 to 7 .

Any item with a median

Frequency of use The intended frequency of use was determined for each food item. Participants had to indicate how often in a period of 30 days they would be willing to consume each food item. (See Method for categories used)

Protein-rich dishes The seven beef dishes (roast beef, steak, T-bone steak, beef stew, corned beef, curried beef and oxtail) were familiar to the majority ( $\geq$ $88 \%$ ) of black participants and were evaluated as high-preference items. The median values were five and higher, indicating that $50 \%$ and more of the participants liked beef dishes. The high-preference ratings for beef dishes were supported by the intended frequency of use, as most of the participants indicated that they would eat beef dishes often (4-10 out of 30 days). The high-preference ratings were similar to the ratings given by the white and coloured participants (Viljoen \& Gericke, 2001).

The five mutton dishes (roast leg of mutton, fried mutton chops, curried mutton, mutton stew and fried mutton ribs) were familiar to the majority ( $\geq 84 \%$ ) of black participants and similar high-preference ratings were obtained as for the beef dishes.

Although the seven pork dishes (roast pork, fried pork chops, sweet-and-sour pork, pork sausage, bacon 
TABLE 4:

FOODS CONSUMED HABITUALLY (3-4 TIMES PER WEEK) BY $\geq 40 \%$ OF BLACK SERVICEMEN $(\mathrm{N}=640)$ AT MEALS AND BETWEEN MEALS

\begin{tabular}{|c|c|c|c|c|c|}
\hline & $\begin{array}{c}\text { NORTH SOTHO } \\
\mathrm{N}=163 \\
\%\end{array}$ & $\begin{array}{c}\text { SOUTH SOTHO } \\
\mathbf{N}=68 \\
\%\end{array}$ & $\begin{array}{c}\text { TSWANA } \\
\mathrm{N}=102 \\
\%\end{array}$ & $\begin{array}{c}\text { XHOSA } \\
\mathbf{N}=88 \\
\%\end{array}$ & $\begin{array}{c}\text { ZULU } \\
\mathrm{N}=219 \\
\%\end{array}$ \\
\hline \multicolumn{6}{|l|}{ Breakfast } \\
\hline Cooked porridge & 43 & 45 & 52 & 58 & 50 \\
\hline Milk with porridge / cereal & - & 52 & 48 & 44 & 48 \\
\hline Bread/toast & 64 & 62 & 52 & 60 & 60 \\
\hline Egg & 56 & 72 & 68 & 70 & 72 \\
\hline Cheese & - & 44 & 58 & 45 & 52 \\
\hline Coffee & - & - & - & 46 & - \\
\hline \multicolumn{6}{|l|}{ Lunch } \\
\hline Bread with margarine & 57 & 45 & 48 & 61 & 58 \\
\hline Porridge and meat & 80 & 78 & 78 & 55 & 66 \\
\hline Rice & 42 & 47 & 50 & 55 & 62 \\
\hline Potatoes & - & 50 & 41 & 58 & 62 \\
\hline Chips (French fries) & - & - & 40 & - & - \\
\hline Vegetables/salads & - & 47 & 45 & 51 & 48 \\
\hline Milk to drink & - & 54 & 45 & 63 & 54 \\
\hline Fizzy cold drinks & - & 40 & 40 & - & - \\
\hline Tea/coffee & - & - & - & 40 & - \\
\hline Milk in tea/coffee & - & - & - & 40 & - \\
\hline \multicolumn{6}{|l|}{ Supper } \\
\hline Meat, fish, chicken & 66 & 75 & 75 & 78 & 82 \\
\hline Rice & - & 50 & 55 & 61 & 68 \\
\hline Potatoes & - & 48 & 44 & 64 & 64 \\
\hline Porridge & 68 & 68 & 74 & 42 & 52 \\
\hline Vegetables/salad & - & 48 & 47 & 48 & 42 \\
\hline Eggs & - & 49 & 42 & - & - \\
\hline Bread & - & 41 & - & 48 & 42 \\
\hline Fruit & - & - & - & - & 40 \\
\hline Milk to drink & - & - & 42 & 40 & - \\
\hline \multicolumn{6}{|l|}{ Between meals } \\
\hline Fruit/ dried fruit & 51 & 58 & 53 & 57 & 42 \\
\hline Chocolate bars & - & 42 & 61 & - & - \\
\hline Cake/ biscuits & - & 54 & 48 & 40 & 40 \\
\hline Cheese & - & 46 & - & - & - \\
\hline Potato crisps & - & - & 42 & - & - \\
\hline Bread with spreads & - & - & - & - & 40 \\
\hline Peanuts & 48 & 46 & 58 & 46 & 50 \\
\hline
\end{tabular}


TABLE 5: $\quad$ VEGETABLES AND VEGETABLE DISHES UNKNOWN TO OR NEVER CONSUMED BY $\geq 20 \%$ OF BLACK SERVICEMEN $(\mathrm{N}=640)$

\begin{tabular}{|c|c|c|c|c|c|}
\hline Vegetable item & $\begin{array}{c}\text { North Sotho } \\
n=163 \\
\%\end{array}$ & $\begin{array}{c}\text { South Sotho } \\
n=68 \\
\%\end{array}$ & $\begin{array}{c}\text { Tswana } \\
\mathrm{n}=102 \\
\%\end{array}$ & $\begin{array}{c}\text { Xhosa } \\
n=88 \\
\%\end{array}$ & $\begin{array}{c}\text { Zulu } \\
\text { n }=219 \\
\%\end{array}$ \\
\hline Sweet-and-sour beetroot & - & - & - & - & 20,55 \\
\hline Buttered cauliflower & 23,31 & 20,59 & - & - & 26,03 \\
\hline Cauliflower with white/ cheese sauce & 25,77 & - & - & - & 22,83 \\
\hline Brussels sprouts, buttered & 41,10 & 35,29 & 35,29 & 38,37 & 47,95 \\
\hline Brussels sprouts, with white/ cheese sauce & 38,04 & 35,29 & 35,29 & 35,23 & 44,75 \\
\hline Broccoli, buttered & 42,33 & 36,76 & 34,31 & 39,77 & 47,03 \\
\hline Broccoli with cheese/ white sauce & 42,95 & 32,35 & 29,41 & 38,64 & 39,27 \\
\hline Hubbard pumpkin & 39,26 & 25,00 & 32,35 & 23,86 & 31,96 \\
\hline Pumpkin fritters & 30,67 & 22,06 & 29,41 & 22,73 & 34,70 \\
\hline Gems, buttered & 42,94 & 30,88 & 37,25 & 32,95 & 45,21 \\
\hline Gems, buttered with sugar & 40,49 & 29,41 & 38,24 & 32,95 & 46,58 \\
\hline Baby marrows & 48,47 & 39,71 & 49,02 & 44,32 & 49,32 \\
\hline Eggfruit, fried & 34,36 & 32,35 & 40,20 & 29,55 & 39,27 \\
\hline Eggfruit, with tomatoes and onions & 30,06 & 26,47 & 40,20 & 30,68 & 35,62 \\
\hline Celery & 39,26 & 44,12 & 44,12 & 42,05 & 48,46 \\
\hline Stir-fry vegetables & 24,54 & 25,00 & - & 22,73 & 30,59 \\
\hline Turnips & 45,50 & 29,41 & 40,20 & - & 33,33 \\
\hline Achaar & - & - & - & - & 25,11 \\
\hline Cucumber salad & 22,09 & - & - & - & 24,20 \\
\hline Lettuce & 22,70 & - & - & - & - \\
\hline Greek salad & 36,81 & 48,53 & 37,25 & 39,77 & 39,73 \\
\hline French salad & 35,58 & 42,65 & 35,29 & 44,32 & 42,01 \\
\hline
\end{tabular}

and ham) were familiar to the majority $(\geq 58 \%)$ in the different groups, there were a few exceptions. The following items were unfamiliar to, or have never been eaten before by some of the participants. In the Zulu group $24,66 \%$ and $28,31 \%$ respectively were unfamiliar with crumbed pork chops and sweet-and-sour pork. Ham was unfamiliar to $\geq 20 \%$ of the participants (North Sotho 26,99\%; South Sotho $23,53 \%$; Tswana $22,55 \%$; Xhosa 21,59\%; Zulu 42,01\%). Crumbed pork chops have never been consumed by $20,09 \%$ of the Zulus, sweet-and-sour pork by $23,31 \%$ of the North Sothos and $23,29 \%$ of the Zulus.

Leg of pork, fried pork chops and bacon were highpreference items for all the ethnic groups. The median values were five and higher, except for leg of pork and fried pork chops for the North Sotho and Tswana groups. Neutral preference was expressed by The North Sothos expressed a neutral preference for leg of pork and fried pork chops, as did the Tswanas. The preference evaluations were supported by the results from the intended frequency of use. More than $21 \%$ of the participants indicated that they would eat leg of pork, fried pork chops and bacon often (4-10 out of 30 days).

Crumbed pork chops were a neutral preference item for all the groups except the Xhosas who rated it a high-preference item. Sweet-and-sour pork was not a familiar dish to some of the groups and was evaluated as a low-preference item by the North Sothos, Tswanas and Xhosas, and a neutral preference item by the South Sothos and Zulus.

Pork sausage was evaluated a high-preference item by all the groups except the North Sothos and the Tswanas who rated it a neutral preference item

Ham was evaluated a high-preference item by the South Sothos and the Zulus and as a neutral preference item by the other groups. 
Pork was not part of the traditional eating pattern of the blacks (Quin, 1959:104) and according to Oudkerk (1965), eating pork was a general taboo. Members of the Zionist church group were also prohibited from eating pork (Manning et al, 1974). The results of this study indicated that this taboo is no longer strictly observed. More than $58 \%$ of the participants who indicated that they were familiar with pork dishes and products, also indicated that they have eaten them before. The preference ratings for the different items differed between the ethnic groups.

All six chicken dishes (fried chicken, chicken stew, curried chicken, Kentucky fried chicken, chicken pie and chicken liver) were familiar to and have been eaten before by $\geq 20 \%$ of the participants in all the ethnic groups. Several ethnic groups traditionally kept chickens and used them as food (Quin, 1959:105; Franz, 1971). The studies of Crous and Borchardt (1982, 1984) and Steyn et al (1993) reported that chicken was regularly consumed.

All the ethnic groups evaluated chicken dishes as high-preference items. Median values of five and higher indicated that $\geq 50 \%$ of the participants liked chicken dishes. The intended frequency of use supported the high-preference ratings. Twenty-eight per cent to $50 \%$ of the participants in each ethnic group indicated that they often consumed chicken dishes (410 out of 30 days), and some instances said even twice per week (11-30 out of 30 days). These results correspond with the findings of other studies (Vawter \& Konishi, 1958; Meiselman \& Waterman, 1978; Viljoen, 1995).

Five organ meat dishes (pickled tongue, kidneys, fried liver, liver cakes and tripe) were evaluated. All the ethnic groups rated chicken liver and fried liver as high-preference items. Median values of five were obtained and the intended frequency of use supported these ratings. Pickled tongue was unfamiliar to approximately $30 \%$ of the participants. They rated it either a neutral or a low-preference item. All the ethnic groups except the Xhosas and North Sothos rated kidney a neutral preference item. The Xhosas rated kidney high-preference item. The North Sothos on the other hand disliked kidney. Liver patties obtained different ratings from the various groups. Although indicated as unknown by $12 \%-30 \%$ of the participants in some groups, it was rated a high-preference item by the North Sothos, Tswanas and Zulus. The Xhosas and South Sothos rated it a neutral preference item. At least $44 \%$ of these groups did not indicate intended frequency of use. All groups rated tripe a neutral preference item. At least $51 \%$ of the participants did not indicate an intended frequency of use.

Ten minced meat dishes were evaluated, namely hamburger patties, meat balls, bobotie, savoury mince, curried mince, boerewors, spaghetti bolognaise, cottage pie and sausage roll. As did the whites and coloureds, the black groups also rated minced meat dishes, except bobotie and savoury mince, as high-preference items. The intended frequency of use supported these ratings as most of the participants indicated that they often (4-10 out of 30 days) consumed these dishes. Bobotie was unknown to $>48 \%$ of the participants and rated a neutral preference item. The North Sothos and Tswanas indicated a dislike of this dish. Forty-six per cent of the participants were unfamiliar with bobotie and indicated no intended frequency of use. It should be kept in mind that $\geq 50 \%$ of the participants in some groups have never eaten bobotie. Savoury mince was unknown to some of the groups ( $\pm 25 \%$ of the Xhosas and Sotho groups and $40 \%$ of the Zulus). The North Sothos and Zulus rated savoury mince a neutral preference item. At least $36,4 \%$ of the participants did not indicate an intended frequency of use for savoury mince.

Five processed-meat products (polony, frankfurters, Vienna sausage, Russian sausage and Bully Beef) were evaluated. With the exception of frankfurters, all the ethnic groups rated these items as highpreference items. Similar high-preference ratings were given by the white and coloured groups (Viljoen \& Gericke, 2001).

Frankfurters were unknown to some $50 \%$ of the participants. The Tswanas and Xhosas rated it a highpreference item and the North Sothos, South Sothos and Zulus rated it a neutral preference item. Unfamiliarity with this food should be taken into account when the results for frankfurters are interpreted. Processed-meat products may be considered "typical" to the Western eating pattern. Those participants who were familiar with these products indicated that they have eaten them before. Frankfurter sausages are a speciality product and not as readily available in the retail market as other processed-meat products. This could explain the relative unfamiliarity of the product.

Texturised vegetable protein dishes were unknown to $\geq 30 \%$ of the North Sotho, Tswana, Xhosa and Zulu participants. These products were rated neutral preference items by all except the Xhosas, Zulus and South Sothos. The Xhosas, Zulus and South Sotho rated these dishes high-preference items, whereas $>50 \%$ of the other groups were neutral or did not like texturised vegetable protein products. Twenty-seven per cent of the participants indicated no intended frequency of use for these products.

Eight fish dishes (fish fried in batter, fish cakes, sardines, pilchards in tomato sauce, haddock, tuna, fish fingers and curried fish) were evaluated. With the exception of haddock, tuna and fish fingers, these dishes were familiar to most $(\geq 84 \%)$ of the participants. All the ethnic groups rated fried fish, fish cakes, pilchards in tomato sauce and curried fish as high-preference items. All the groups rated sardines a neutral preference item. Haddock was unfamiliar to approximately $50 \%$ of the participants. The Tswanas rated it a high-preference item whereas the other groups rated it a neutral preference item. Forty-four per cent of the participants were not familiar with haddock and the intended frequency of use was therefore not indicated. Around $\geq 39 \%$ of the participants were 
not familiar with tuna. All the groups expressed a neutral preference rating for tuna. In view of the unfamiliarity with this item no intended frequency of use was indicated by $\geq 61 \%$ of the participants. Fish fingers were unfamiliar to $30 \%$ to $45 \%$ of the black ethnic groups. With the exception of the Tswanas and Zulus, the other groups rated fish fingers a neutral preference item. The Tswanas and Zulus rated fish fingers a high-preference item. The majority $(\geq 50 \%)$ of the participants indicated no intended frequency of use. The unfamiliarity of this item should be kept in mind when these results are interpreted.

Traditionally fish was taboo for some black ethnic groups, for example the North Sotho (Quin, 1959:128), the Tswana-Sotho groups (Franz, 1971) and the Zulus (Manning et al, 1974). Various studies (Quin, 1959:128; Oudkerk, 1965; Lubbe \& Maree, 1973) indicated that this taboo fell into disuse and that fish consumption among the black ethnic groups has increased. Popular fish dishes were tinned fish, sardines and fried fish (Oudkerk, 1965; Lubbe \& Maree, 1973; Manning et al, 1974; Crous \& Borchardt, 1982).

All six cheeses and cheese dishes (cheddar, sweet milk, pizza, macaroni and cheese, toasted cheese sandwiches and cottage cheese) were familiar to these respondents and they have eaten all six before. These items were all rated a high-preference items. The results were supported by the intended frequency of use, indicated as often (4-10 out of 30 days). Contrary to the white and coloured groups, cottage cheese was rated a high-preference item.

Although cheese was not part of the traditional eating pattern of the black groups, cheese and cheese-based dishes appeared to have become part of their eating patterns (Manning et al, 1974; Crous \& Borchardt, 1982,1984). The results of this study indicated that the majority $(\geq 72 \%)$ of the participants were familiar with cheese and cheese-based dishes and have eaten them before.

All the groups rated plain and flavoured yoghurt a high-preference item. The intended frequency of use supported these results as yoghurt was consumed often (4-10 out of 30 days) and sometimes twice per week (11-30 out of 30 days).

With the exception of the omelette, the other egg dishes (soft-boiled egg, hard-boiled egg, scrambled egg and French toast) were familiar to the majority $(\geq$ $83 \%$ ) of the black participants. Some $50 \%$ to $60 \%$ of these participants did not know what an omelette was. All the groups rated all the other egg dishes as highpreference items. The high preference rating for egg dishes was supported by the intended frequency of use, indicated as often (4-10 out of 30 days) to twice per week (11-30 out of 30 days). A large percentage $(\geq 56 \%$ ) of the participants indicated that eggs were part of their habitual eating pattern. Traditionally eggs were taboo to most black ethnic groups, specifically to females of childbearing age, boys and young men (Cassel, 1957; Van Wyk, 1990). However, Crous and
Borchardt (1982) reported that eggs were regularly consumed by men, women and children in Atteridgeville and that the egg taboo was fast disappearing.

Starch dishes All five potato dishes (boiled potatoes, mashed potatoes, jacket potatoes, potato salad and potato chips) were familiar to most ( $\geq 91 \%)$ of the participants. With the exception of jacket potatoes, the other dishes were rated a high-preference items. Jacket potatoes was rated a neutral preference item by all the black groups with the exception of the North Sothos who rated it a high-preference item. The preference ratings were supported by the intended frequency of use, indicated as often (4-10 out of 30 days). According to Manning et al (1974), potatoes were one of the first vegetables to be included in the traditional diet after urbanisation. With the exception of the North Sothos, $41 \%$ of the other participants indicated that potatoes were consumed often (3-4 times per week) at lunch and supper.

The two sweet potato dishes (cooked sweet potato and sweet potato fried in butter and sugar) were familiar to all the participants. With the exception of the South Sotho who rated sweet potatoes fried in butter and sugar a neutral preference item, the other groups rated both dishes as high-preference items. The intended frequency of use supported these ratings as most participants indicated it as often (4-10 out of 30 days). Sweet potatoes and potatoes have been an item in the traditional eating pattern of some of the black ethnic groups such as the Zulus (Bryant, 1939:3), the North Sothos (Quin, 1959:59), the Vendas (Crous \& Borchardt, 1986) and other groups (Bruwer, 1963:109). Various other studies have found that potatoes and sweet potatoes were consumed regularly (Oudkerk, 1965; Crous \& Borchardt, 1984).

Five rice dishes (cooked rice, yellow rice with raisins, brown rice, savoury rice and rice salad) were evaluated. All the groups rated cooked white rice, yellow rice with raisins and rice salad as high-preference items. The intended frequency of use supported these ratings, indicated as twice per week (11-30 out of 30 days) for white rice and as often (4-10 out of 30 days) for yellow rice with raisins and for rice salad. Brown rice and savoury rice were rated neutral preference items and were not known to a considerable percentage of participants. Between $23 \%$ and $32 \%$ of the participants were not familiar with brown rice, and $32 \%$ of the participants in some groups did not know what savoury rice was. The intended frequency of use was indicated as often for brown rice, but $45,5 \%$ to $57,1 \%$ gave no indication of how frequently they used savoury rice, possibly because they were not familiar with the item. The fact that the participants were not familiar with brown rice could be because it was relatively new on the market and perhaps not readily available in all areas. Savoury rice may be considered a typical Western dish, and this could explain its unfamiliarity. Although rice was not part of the traditional eating pattern, the inclusion of rice in the eating patterns of black ethnic groups has been well documented (Oudkerk, 1965; Lubbe \& Maree, 
1973; Manning et al, 1974; Crous \& Borchardt, 1984; Bourne et al, 1994).

Six dishes in the pulse/legume group (lentils, dried beans, dried peas, soya beans, baked beans and baked beans in tomato sauce) were evaluated. Lentils were relatively unknown to the participants as the North Sothos $(49,69 \%)$, South Sothos $(38,42 \%)$ Tswanas $(42,16 \%)$, Xhosas $(40,91 \%)$ and Zulus $(37,9 \%)$ all indicated that lentils were unfamiliar to them. Only the study by Manning et al (1974) reported that lentils were used by blacks. With the exception of the Zulus, lentils were rated a neutral preference item. The Zulus disliked lentils. Few of the participants $(58,0 \%-69,3 \%)$ indicated an intended frequency of use, probably because few were familiar with this product.

Baked beans and baked beans in tomato sauce were familiar to all the groups and were rated highpreference items. The preference ratings were supported by the intended frequency of use (4-10 out of 30 days). With the exception of the Xhosas, the groups rated dried beans and dried peas neutral preference items. The Xhosas rated these two dishes as high-preference items. The intended frequency of use for dried beans was indicated as often (4-10 out of 30 days), and was not indicated for dried peas by $20,1 \%$ to $32,5 \%$ of the participants.

Soya beans were unknown to approximately $20 \%$ of the participants. With the exception of the Xhosas, the other black groups rated soya beans a neutral preference item. The Xhosas rated soya beans a high-preference item.

Eight maize dishes (creamed sweet corn, pitted mealies, corn on the cob, mealie rice, samp, stiff maize meal porridge, crumbed maize meal porridge and soft maize meal porridge) were evaluated. Some of the groups were not familiar with a number of these dishes. Creamed sweet corn was not known to the North Sothos $(26,83 \%)$, South Sothos $(26,47 \%)$ and Zulus $(31,51 \%)$, and pitted mealies were unfamiliar to the North Sothos $(24,54 \%)$, South Sothos $(27,94 \%)$ and Zulus $(33,33 \%)$. The reason why these two items were not familiar could be because both are commercially processed products and are not readily available in shops in rural areas. Corn on the cob was indicated as not familiar to $\geq 28 \%$ of the black participants (North Sothos $(28,22 \%)$, South Sothos $(30,88 \%)$, Tswanas $(29,41 \%)$, Xhosas $(31,82 \%)$ and Zulus $(41,55 \%)$ ). Green mealies (corn on the cob) are very popular, however, and are sold by street vendors in both rural and urban areas. The reason for the reported unfamiliarity is probably because the term "corn on the cob" - an unfamiliar term in South Africa - was used in the questionnaire.

Porridge-based dishes were traditionally prepared from maize meal (Bryant, 1939:3; Quin, 1959:37; Coetzee 1982:130-143) and cooked whole maize kernels and roasted maize dishes were prepared to a lesser extent (Bryant, 1939:4; Quin, 1959:37; Coetzee,
1982:123-127. Most of the other maize dishes were rated high-preference items. Similar results were reported in the American studies of Knickrehm et al (1969) and Meiselman and Waterman (1978) who found that maize dishes were high-preference items - with the exception of a few maize dishes in some ethnic groups.

All the groups rated samp, stiff maize meal porridge and crumbed maize meal porridge as high-preference items. The intended frequency of use supported these ratings as the participants indicated that they often (4-10 out of 30 days) used these items. The intended frequency of use for porridge was even indicated as twice per week (11-30 out of 30 days). With the exception of crumbed maize meal porridge for the North Sothos, the median value was five, indicating a liking for these items. The median value of crumbed maize meal porridge among the North Sothos was four.

Only the Sotho groups rated mealie rice a highpreference item. The Xhosas and Zulus rated it a neutral preference item. All the groups indicated the intended frequency of use as often. Creamed sweet corn was rated a high-preference item by all the groups except the North Sothos who rated it a neutral preference item. The intended frequency of use was often (4-10 out of 30 days) for $\geq 17 \%$ of the participants. The exceptions were the North Sothos $(44,8 \%)$ and Zulus $(47,9 \%)$ who did not indicate an intended frequency of use because they were not familiar with the item.

Pitted mealies were rated a neutral preference item by most groups, except the South Sothos and Xhosas who rated it a high-preference item. Between 16,4\% and $25,0 \%$ of participants indicated the intended frequency of use as often (4-10 out of 30 days). The Zulus were the exception, however, as $33 \%$ were not familiar with pitted mealies.

All the groups rated corn on the cob/green mealies a high-preference item. Median values of five were obtained from all the groups except the North Sothos who gave a median value of four. Between 15,5\% and $23,9 \%$ of the participants in all the groups indicated the intended frequency of use as often (4-10 out of 30 days).

Five pasta dishes (spaghetti, spaghetti in tomato sauce, macaroni, noodles and noodle salad) were evaluated. Only noodles and noodle salad were not familiar to some of the respondents. The South Sothos (48,53\%), Tswanas $(49,02 \%)$, Xhosas $(45,45 \%)$ and Zulus $(52,05 \%)$ were not familiar with noodles, and the North Sothos $(30,06 \%)$, South Sothos $(35,29 \%)$, Tswanas $(27,45 \%)$, Xhosas $(36,36 \%)$ and Zulus $(40,18 \%)$ were not familiar with noodle salad. Pasta dishes are typical Western food items and were not part of the traditional eating pattern of the black ethnic groups. The findings of this study showed, however, that most $(>51 \%)$ of the participants in the black ethnic groups were familiar with 
pasta dishes and had eaten them before - probably due to the influence of acculturation.

All the groups rated spaghetti, spaghetti in tomato sauce and macaroni as high-preference items. The intended frequency of use was indicated as often (410 out of 30 days). All the ethnic groups rated noodles and noodle salad as neutral preference items. Due to the unfamiliarity of these items, the majority $(\geq$ $53 \%$ ) did not indicate an intended frequency of use.

Pearled wheat was unknown to some of the North Sothos $(23,31 \%)$, South Sothos $(36,76 \%)$, Xhosas $(23,86 \%)$ and Zulus $(39,27 \%)$. Pearled wheat was not part of the traditional eating pattern of the black groups. Grains that were traditionally cultivated were sorghum, millet and maize (Bryant, 1939:2-3; Quin,1959:24-37; Coetzee,1982:67-68). With the exception of the Tswanas and Xhosas who rated pearled wheat a high-preference item, all the groups rated pearled wheat a neutral preference item. The intended frequency of use was not indicated by $\geq 41 \%$ of the participants - probably because of the unfamiliarity of the item.

Most of the vegetable dishes $(60 \%)$ were familiar to the participants who have eaten these dishes before. The exceptions were vegetable dishes prepared from certain cabbage varieties and some pumpkin dishes (see Table 5).

\begin{abstract}
Vegetables Dishes from the cabbage family (cauliflower, Brussels sprouts, broccoli and cabbage) were evaluated. Although cabbage was not part of the traditional eating pattern of the black ethnic groups, several studies have indicated that cabbage was frequently included in the diets of urban and rural black people and that it has become a popular vegetable (Oudkerk, 1965; Lubbe \& Maree, 1973; Manning et al, 1974; Crous \& Borchardt, 1984; Steyn et al, 1993). Cabbage dishes prepared from leafy cabbage varieties were familiar to most of the participants.
\end{abstract}

As indicated in Table 5, some cabbage varieties (cauliflower, Brussels sprouts and broccoli) were not familiar to or have never been eaten by $20 \%$ or more of the participants. These varieties are typically associated with the Western eating pattern and may be considered relatively expensive vegetables. This could explain the high percentage of participants who were unfamiliar with or have never eaten these dishes before.

As in other preference studies (Schuck, 1961; Viljoen, 1995), it was also found that some cabbage varieties were not very popular. However, as indicated before, some of these varieties were unfamiliar to the black groups. Buttered cauliflower was rated a highpreference item by the Zulus and a low-preference item by the North Sothos, South Sothos and Xhosas. The median value for all the participants was four, indicating a neutral preference for buttered cauliflower. Cauliflower with cheese / white sauce was rated a high-preference item by the North Sothos and Tswa- nas. The other groups rated it a neutral or lowpreference item. The intended frequency of use was not indicated due to the unfamiliarity of the item. Brussels sprouts and broccoli were unfamiliar to a large percentage $(40 \%-50 \%)$ of the black participants. The median values were four and lower than four, indicating that the black groups did not like these items.

Buttered cabbage was rated a high-preference item by the Tswanas and Xhosas and a neutral preference item by the other groups. All the groups rated cabbage with potatoes and onions and coleslaw as highpreference items. The intended frequency of use was indicated as often (4-10 out of 30 days). Cabbage with white / cheese sauce was rated a neutral preference item by all the groups except the Zulus. The Zulus rated cabbage with white / cheese sauce a high-preference item.

The green bean dishes (buttered green beans, green beans with potatoes and onions and curried green beans) were familiar to all the groups and were rated as high-preference items by all the participants. The intended frequency of use was indicated as often (410 out of 30 days).

All the groups were familiar with the beetroot dishes (cooked beetroot, beetroot salad and sweet-and-sour beetroot). All the participants rated cooked beetroot and beetroot salad as high-preference items. All the groups rated sweet-and-sour beetroot a neutral preference item. The intended frequency of use for the three beetroot dishes was indicated as often (4-10 out of 30 days) by all the participants except the Zulus. The intended frequency of use for sweet-and-sour beetroot was not indicated by $35,2 \%$ of the Zulus.

Four carrot dishes (buttered carrots, carrots with potatoes and onions, carrots with orange sauce and carrot salad) were evaluated. All the groups rated buttered carrots, carrots with potatoes and onions and carrot salad as high-preference items. The median value was five, with the exception of the North Sothos and Tswanas who gave a median value of four for carrots with potatoes and onions. The intended frequency of use was indicated as often (4-10 out of 30 days). All the groups rated carrots with orange sauce a neutral preference item. The intended frequency of use was not indicated by $25 \%-33,3 \%$ of the participants. Carrot salad was rated a high-preference item and $\geq 29 \%$ of all the participants indicated that they would eat carrot salad often (4-10 out of 30 days).

Two pea dishes (buttered peas and buttered peas with sugar) were evaluated. With the exception of the North Sothos and Zulus, the other groups rated buttered peas a high-preference item. The North Sothos and Zulus rated it a neutral preference item. However, all the groups rated buttered peas with sugar a neutral preference item. The intended frequency of use was indicated as often (4-10 out of 30 days) for both dishes. 
The pumpkin varieties (Boer pumpkin, Hubbard squash, gem squash and baby marrow) were evaluated. Buttered pumpkin and pumpkin with sugar and butter were rated high-preference items (median values of five). The intended frequency of use was indicated as often (4-10 out of 30 days). All the groups except the North Sothos rated pumpkin fried with butter and sugar a high-preference item. The North Sothos rated it a neutral preference item. The intended frequency of use was indicated as often (4-10 out of 30 days) and even twice per week (11-30 out of 30 days).

Between $22 \%$ and $45 \%$ of the participants in some groups were not familiar with the Hubbard squash and pumpkin fritters, or have never eaten either dish. With a few exceptions these items were rated highpreference items. The median value for Hubbard squash was four with the exception of the North Sothos and Tswanas who gave median values of five. Fifty per cent and more of the North Sothos and Tswanas participants liked Hubbard squash. The median value for pumpkin fritters was five for the Tswanas whereas the other groups felt neutral about this pumpkin variety.

Buttered gem squash with nutmeg and buttered gem squash with sugar were not familiar to a considerable percentage of the blacks $(30 \%-50 \%)$. With few exceptions, these two items were rated as neutral preference items. Only the Tswanas rated both dishes as high-preference items. Not all $(54,7 \%)$ the participants indicated the intended frequency of use. The unfamiliarity of these items should be kept in mind when the results are interpreted. A large percentage of the participants $(40 \%-49 \%)$ were unfamiliar with baby marrows and all the groups rated it a neutral preference item. The intended frequency of use was seldom indicated.

Pumpkin dishes were traditionally part of the meal pattern of the different black ethnic groups (Bryant, 1939:2; Quin, 1959:55-57; Coetzee, 1982:69). Some pumpkin dishes were familiar to the participants, for example buttered pumpkin, pumpkin with sugar and butter, and pumpkin fried with butter and sugar. The pumpkin dishes Table 5 lists as unknown or never eaten before, could be because the preparation methods were unfamiliar to the black participants. Moreover, these dishes could be described as typical of Western cuisine. Manning et al (1974) reported that vegetables were considered "food for women". Zulu men allegedly did not like vegetables and Xhosa men allegedly did not eat pumpkin dishes.

All the groups rated spinach (buttered spinach and spinach with tomatoes and onions) a high-preference item (median values of five). The intended frequency of use was indicated as often (4-10 out of 30 days). These findings were contrary to the preference ratings of the whites and coloureds (Viljoen \& Gericke, 2001). The whites indicated a low preference for these two items, and the coloureds indicated a neutral preference. The intended frequency of use was indicated as never by $52 \%$ of the whites and as often (4-10 out of 30 days) by $24 \%$ of the coloured respondents.

All the groups except the Zulus rated two onion dishes (fried onions and onions fried in batter) as high-preference items. The Zulus rated both as neutral preference items. Meiselman and Waterman (1978) interestingly found that fried onions were a high-preference item of American soldiers. All the black ethnic groups rated onion salad a neutral preference item (median value of four). All the groups indicated the intended frequency of use as often (4-10 out of 30 days).

All the groups rated tomatoes and tomato salad as high-preference items (median values of five). The intended frequency of use was indicated as often (410 out of 30 days) and even as twice per week (11-30 out of 30 days). Schuck (1961), Knickrehm et al (1969) and Viljoen (1995) also reported a high preference rating for tomatoes.

Some of the other vegetable dishes were unknown to or have never been eaten by $20 \%$ or more of the participants. (See Table 5 for information on eggfruit, stirfry vegetables, achaar, celery and turnips.) These food items were not part of the traditional eating pattern of the black ethnic groups. Most of these vegetable dishes - with the exception of achaar - could be described as typical of the Western eating pattern. These dishes were not mentioned or referred to in any of the previous studies on the eating patterns of black groups after urbanisation.

All the groups rated buttered mixed vegetables as high-preference item, with an intended frequency of use indicated as often (4-10 out of 30 days).

Fried eggfruit and eggfruit with tomatoes and onions were unfamiliar to between $30 \%$ and $40 \%$ of the participants. The Tswanas, Xhosas and Zulus rated fried eggfruit a high-preference item, whereas the North Sothos and South Sothos rated it a neutral preference item. The intended frequency of use was not indicated by $\geq 47 \%$ of the participants, probably due to the unfamiliarity of the items. All the groups, with the exception of the North Sothos, rated eggfruit with tomatoes and onions a high-preference item. The North Sothos rated it a neutral preference item.

With the exception of the Zulus, the other groups rated mushrooms a low-preference item. The Zulus rated it a neutral item. The intended frequency of use was indicated as never by $\geq 22,8 \%$ of the participants.

Celery was unfamiliar to between $40 \%$ and $60 \%$ of the participants. Celery was rated a neutral preference item by the North Sothos, Tswanas and Zulus, and the South Sothos and Xhosas rated it a lowpreference item. Most did not indicate the intended frequency of use $(\geq 65,8 \%)$, probably due to its unfamiliarity. 
With the exception of the South Sothos and Zulus, all the other groups rated stir-fried vegetables a highpreference item. The South Sothos and Zulus rated it a neutral preference item. Some $45,5 \%$ of the participants did not indicate the intended frequency of use - probably due to its unfamiliarity.

All the groups rated turnips a neutral preference item. The intended frequency of use was not indicated due to unfamiliarity with the item.

The Xhosas (19\%) and Zulus (25\%) were not familiar with achaar. All the groups except the Zulus, who rated it a neutral preference item, rated achaar a highpreference item.

All the groups rated green peppers a neutral preference item. The intended frequency of use varied, however. Some groups indicated often (4-10 out of 30 days) and others gave no indication.

Salads Vegetables were traditionally not served as salads and salads as such did not form part of the eating pattern of the black ethnic groups. Although $20 \%$ or more of the participants indicated some vegetable salads as unknown or never eaten (see Table 5 for information on cucumber salad, lettuce, Greek salad and French salad), those participants who indicated familiarity with salad dishes tended to rate these as high or neutral preference items. Increased vegetable salad consumption was also reported by Grivetti (1978) and Crous and Borchardt (1982, 1984).

All the groups rated mixed vegetable salad a highpreference item with an intended frequency of use indicated as often (4-10 out of 30 days).

All the groups rated cucumber salad a neutral preference item. However, no intended frequency of use was indicated by $\geq 36,8 \%$ of the participants.

The Tswanas and Xhosas rated lettuce a highpreference item whereas the other groups rated it a neutral preference item. No intended frequency of use was indicated by $\geq 29,7 \%$ of the participants.

The South Sothos and Xhosas rated mixed salad a high-preference item. The North Sothos, Tswanas and Zulus rated it a neutral preference item. No intended frequency of use was indicated by $\geq 27,9 \%$ of the participants.

Greek salad was unfamiliar to a considerable percentage of the black participants. Except the South Sothos, the other groups gave a neutral preference rating. The South Sothos rated it a low-preference item. No intended frequency of use was indicated by the majority $(\geq 62,6 \%)$ of the participants.

French salad was rated a neutral preference item by all the groups except the Tswanas. The Tswanas rated it a high-preference item. Due to the unfamiliarity of French salad, the majority $(\geq 60,1 \%)$ indicated no intended frequency of use.
All the groups rated pineapple slices and banana salad as high-preference items. The intended frequency of use was indicated as often (4-10 out of 30 days).

Fruit With the exception of veld fruit (fruit gathered in the wild), the studied literature did not indicate fruit as part of the traditional eating pattern. However, various studies reported the weekly consumption of fresh fruit by urban black groups (Oudkerk, 1965; Manning et al, 1974; Crous \& Borchardt, 1982). According to other preference studies (Schuck, 1961; Knickrehm et al, 1969; Meiselman \& Waterman 1978; Viljoen, 1995), all the black ethnic groups, with a few exceptions, generally rated fruit a high-preference item. Median values of five and higher indicated that these groups liked fruit. These results were supported by an intended frequency of use of at least twice per week, reported by $24,2 \%$ of the participants. Exceptions were spanspek (melon), watermelon, strawberries and raisins.

Some of the participants said that watermelon, spanspek and raisins were unknown to them. The North Sothos $(22,70 \%)$, Xhosas $(23,86 \%)$ and Zulus $(40,64 \%)$ indicated that they were not familiar with spanspek. The Zulus $(30,14 \%)$ was the only group who indicated that watermelon was unknown to $20 \%$ or more of this group, and raisins were unknown to the North Sothos $(22,70 \%)$ and the Zulus $(21,00 \%)$.

With the exception of the Xhosas, spanspek was rated a high-preference item. The Xhosas rated spanspek a neutral preference item.

Desserts and dessert sauces The items evaluated in this group included ice cream, baked puddings, jelly, instant puddings, canned fruit as well as dessert sauces such as custard and chocolate sauce. With the exception of bread pudding, the other desserts and dessert sauces were rated high-preference items. This was supported by the reported intended frequency of use of often (4-10 out of 30 days). According to other preference studies (Knickrehm et al, 1969; Einstein \& Hornstein, 1970; Meiselman \& Waterman, 1978; Viljoen, 1995), ice cream was the most popular item in the dessert group. Bread pudding was not known to the North Sothos (23\%), South Sothos (13\%) and Zulus (21\%). The Xhosas rated bread pudding a neutral preference item.

Breakfast cereals The cooked breakfast cereals (oats, mabell, Taystee Wheat, soft and stiff mealie meal porridge) were evaluated. With the exception of Taystee Wheat, all were rated high-preference items. Taystee Wheat was not familiar to a large percentage $( \pm 30 \%)$ of the black groups.

The ready-to-eat breakfast cereals (Weet Bix, Post Toasties, Rice Crispies and ProNutro) were evaluated. In comparison to the cooked breakfast cereals The ready-to-eat breakfast cereals were not as familiar to some of the black ethnic groups as the cooked breakfast cereals, (Post Toasties was for example 
unknown to $23 \%$ to $40 \%$ of the participants and All Bran was unknown to $20 \%$ to $40 \%$.) However, breakfast cereals were rated high-preference items by all the groups, and the intended frequency of use was indicated as often (4-10 out of 30 days).

Bread and baked products As in other preference studies (Vawter \& Konishi, 1958; Meiselman \& Waterman, 1978; Einstein \& Hornstein, 1970; Viljoen, 1995), it was found that bread and baked products were rated high-preference items. All the groups rated all types of bread as well as vetkoek as high-preference items (median values of five and higher). Muffins were not familiar to a large percentage $( \pm 40 \%)$ of the black groups. With the exception of the North Sothos and Zulus, muffins were rated a high-preference item. The North Sothos and Zulus were neutral about muffins.

Beverages The different ethnic groups, with a few exceptions, rated beverages as high-preference items. With the exception of the Xhosas and Zulus, rooibos tea was rated a high-preference item (median value of five). The Xhosas and Zulus gave median values of four.

Horlicks was unfamiliar to a large percentage $(40 \%$ $50 \%$ ) of the black participants. With the exception of the Xhosas, the groups rated Horlicks a highpreference item. Fresh milk, as in other preference studies (Vawter \& Konishi, 1958; Schuck, 1961; Einstein \& Hornstein, 1970; Meiselman \& Waterman 1978; Viljoen, 1995), received the highest preference rating of all the evaluated items. The black ethnic groups rated sour milk (maas), maghew and buttermilk high-preference items, whereas the whites and coloureds rated them as low or neutral preference items respectively. As in other preference studies (Einstein \& Hornstein, 1970; Meiselman \& Waterman, 1978; Viljoen, 1995), fizzy drinks and fruit juices were rated high-preference items.

\section{CONCLUSIONS}

Information which contributed to the corpus of knowledge on the food habits and food preferences of the North Sothos, South Sothos, Tswanas, Xhosas and Zulus, was obtained empirically. These five groups follow Western eating patterns in combination with traditional eating patterns. Compared to their traditions, the meal patterns of these black groups have changed, probably as a result of acculturation.

Food habits A meal pattern of three meals per day was identified as a general trend. However, $28 \%$ of the North Sotho participants indicated that they still consumed two meals per day. The studies of Oudkerk (1965), Crous and Borchardt $(1982,1984)$ and Langenhoven et al (1988) also found that the meal pattern differed over weekends, and that the Sunday midday meal tended to be similar to the Western Sunday midday meal.
Maize meal porridge was still the staple food of the studied black groups. Forty per cent of the participants consumed maize meal porridge habitually (3-4 times per week) at all three meals. In addition to the maize meal porridge, however, certain food items that could be described as characteristic of the Western eating pattern and that were not part of the traditional eating pattern of the blacks, were included in meals. These Western foods were eggs and cheese at breakfast, bread at breakfast and lunch, rice and potatoes as starch dishes and vegetables and/or vegetable salads at lunch and supper.

Traditional taboos with regard to the consumption of certain food items did not seem to be enforced as strictly as before, for example taboos on the consumption of eggs, fish and pork. This could be the result of increased exposure to, acceptance and consumption of these items.

Food preferences Culture determines food preferences (Messer, 1984; Krondl \& Coleman, 1986; Parraga, 1990; Van Wyk, 1990). This statement was confirmed by this study. The black groups rated certain food items (such as spinach with tomato and onion, achaar, maghew and sour milk) as high-preference items, whereas the white and coloured groups rated these items as low or neutral preference items. Breakfast cereals, on the other hand, were highpreference items among the whites and coloureds, whereas the black groups (who were not as familiar with breakfast cereals) rated them low or neutral preference items. Only the whites rated mushrooms a high-preference item; the other groups indicated a low or neutral preference for mushrooms. The Xhosas were the only group who rated dried peas, dried beans and soya beans as high-preference items. According to Manning et al (1974), samp and beans were common to the eating pattern of the Xhosas. The other groups rated these legumes as lowpreference items.

\section{REFERENCE LIST}

BOURNE, L T, LANGENHOVEN, M L, STEYN, K, JOOSTE, $P$ L, NESAMVUNI, A E \& LAUBSCHER, J A. 1994. The food and meal pattern in the urban African population of the Cape Peninsula, South Africa. The Brisk Study. Central African Journal of Medicine 40(6):140-148.

BRINK, A \& BOSHOFF, E. 1983. Babavoeding in GaRankuwa, Bophuthatswana: voedselverbruik en maaltydpatrone. Tydskrif vir Dieetkunde en Huishoudkunde 11(1):913.

BRYANT, A T. 1939. A description of native foodstuffs and their preparation. Pretoria. Government Printer.

BRUWER, F P. 1963. Die Bantoe van Suid-Afrika. Hersiene uitgawe. Kaapstad. Afrikaanse Pers Boekhandel.

CASSEL, J. 1957. Social and cultural implications of food and food habits. American Journal of Public Health 47:732740.

COETZEE, R. 1982. Funa food from Africa. Roots of traditional African food culture. Pretoria. Butterworths.

CROUS, J M \& BORCHARDT, S. 1982. Eetgewoontes van Pedi-huisgesinne in Atteridgeville. Tydskrif vir Dieetkunde en Huishoudkunde 10(1):29-31. 
CROUS, J M \& BORCHARDT, S. 1984. Dieetpatrone van Venda-gesinne in Atteridgeville. Tydskrif vir Dieetkunde en Huishoudkunde 12(2):41-44.

CROUS, J M \& BORCHARDT, S. 1986. Dieetpatrone van Venda-gesinne in Tshikunda Malema. Tydskrif vir Dieetkunde en Huishoudkunde 14(2):44-47.

EINSTEIN, M A \& HORNSTEIN, I. 1970. Food preferences of college students and nutritional implications. Journal of Food Science 35:429-436.

FRANZ, H C. 1971. The traditional diet of the Bantu in the Pietersburg District. South African Medical Journal (6 November):1232-1235.

GERICKE G J, BORCHARDT, S \& CROUS, J M. 1987 Venda-kindervoedingpraktyke: stad en platteland. Tydskrif vir Dieetkunde en Huishoudkunde 15(2):48-54.

GRIVETTI, L E. 1978. Nutritional success in a semi-arid land: examination of Tswana agro-pastoralists of the eastern Kalahari, Botswana. American Journal of Clinical Nutrition 31:1204-1220.

HAMMOND-TOOKE, D. 1993. The roots of black South Africa. Johannesburg. Ball.

KNICKREHM M E, COTNER, C G \& KENDRICK, J G. 1969. Acceptance of menu items by college students. Journal of the American Dietetic Association 55:117-119.

KRONDL, M \& COLEMAN, P. 1986. Social and biocultural determinations of food selection. Progress in Food and $\mathrm{Nu}$ trition Science 10:179-203.

LANGENHOVEN M L, WOLMARANS, P, GROENEWALD G, RICHTER, M J C \& VAN ECK, M. 1988. Nutrient intakes and food and meal patterns in three South African population groups. Frontier Gastrointestinal Research 14:41-48.

LEARY, P M. 1969. The diet of Pedi schoolchildren. South African Medical Journal (21 June):792-795.

LESTRADE, G P. 1937. Domestic and communal life. In Shapera, I. The Bantu-speaking tribes of South Africa. An ethnographical survey. London. Routledge \& Kegan Paul.

LUBBE, A M \& MAREE, C M. 1973. Dietary survey in the Mount Ayliff district. South African Medical Journal (24 February):304-307.

MANNING, E B, MANN, J I, SOPHANGISA, E \& TRUSWELL, A S. 1974. Dietary patterns in urbanized blacks. South African Medical Journal (13 March):485-497 MEISELMAN, H L \& WATERMAN, D. 1978. Food preferences of enlisted personnel in the armed forces. Journal of the American Dietetic Association 73:621-629.

MESSER, E. 1984. Socio-cultural aspects of nutrient intake and behavioral responses to nutrition. In Galler, J R. Nutrition and behavior. New York. Plenum.

O'MAHONEY, M. 1986. Sensory evaluation of food. Statistical methods and procedures. New York. Dekker.

OUDKERK, A C F. 1965. Eating habits of urban Bantu, with special reference to the school-going child. South African
Medical Journal (18 December):1148-1150.

PARRAGA, I M. 1990. Determinants of food consumption. Journal of the American Dietetic Association 90(5):661-663.

POPKIN, B M. 1994. The nutritional transition in lowincome countries: an emerging crisis. Nutrition Reviews 52 (9):285-298.

QUIN, P J. 1959. Food and feeding habits of the Pedi. Johannesburg. University of the Witwatersrand Press.

RICHARDSON, B D, SINWEL, R E \& RANTSHO, J M.

1982. The variety of food items consumed by different child populations in South Africa. Ecology of Food and Nutrition 12:29-37.

SCHUCK, C. 1961. Food preferences of South Dakota students. Journal of the American Dietetic Association 39 (12):595-597.

SHAPIRO, S S \& WILK, M B. 1965. An analysis of variance tests for normality. Biometrica 52:591-611.

STEYN, N P, BADENHORST, C J \& NEL, J H. 1993. The meal pattern and snacking habits of schoolchildren in two rural areas of Lebowa. South African Journal of Food Science and Nutrition 5(1):5-9.

VAWTER, H J \& KONISHI, F. 1958. Food acceptance by soldiers under an ad libitum regimen. Journal of the American Dietetic Association 34(1):36-41.

VAN EEDEN, T S \& GERICKE, G J. 1996. Effect of acculturation on habitual food intake and dietary patterns of rural and urban black home economics students. Suid-Afrikaanse Tydskrif vir Voedselwetenskap en Voeding 8(3):85-94.

VAN WYK, J J. 1990. Sosio-kulturele verband van voedsel en voedselverbruike. Tydskrif vir Dieetkunde en Huishoudkunde 18(3):80-85.

VILJOEN, A T. 1995. Kliëntfokus in spyskaartbeplanning: 'n situasie-analise. Tydskrif vir Dieetkunde en Huishoudkunde 23(1):36-41.

VILJOEN, A T. 1996. Eetgewoontes en voedselvoorkeure van mans (16-25 jaar) van die Suid-Afrikaanse bevolking. $M$ Dieetkunde-verhandeling. Pretoria. Universiteit van Pretoria. VILJOEN, A T \& GERICKE, G J. 1998. Methodology for the collection and application of information on food habits and food preferences in menu planning of heterogeneous groups. Journal of Family Ecology and Consumer Sciences 26(2):89-102

VILJOEN A T \& GERICKE, G J. 2001. Food habits and food preferences of white and coloured South African men in the army (1993-1994). Journal of Family Ecology and Consumer Sciences 29:1-12.

WALKER, A R P. 1962. Health hazards in the urbanization in South African populations: a brief review. Journal of Dietetics and Home Economics 10(2):67-71.

WALKER, A R P. 1995. Nutrition-related diseases in Southern Africa: with special reference to urban African populations in transition. Nutrition Research 15(7):1053-1094. 